Please do not remove this page

RMIT

UNIVERSITY

\title{
Three academics' narratives in transforming curriculum for education for sustainable development
}

Wahr, Fiona; Underwood, Jenny; Adams, Luise; Prideaux, Verity

https://researchrepository.rmit.edu.au/esploro/outputs/9921859118501341/filesAndLinks?institution=61RMIT_INST\&index=null

Wahr, F., Underwood, J., Adams, L., \& Prideaux, V. (2013). Three academics' narratives in transforming curriculum for education for sustainable development. Australian Journal of Environmental Education, 29(1), 97-116. https://doi.org/10.1017/aee.2013.21

Document Version: Accepted Manuscript

Published Version: https://doi.org/10.1017/aee.2013.21

Repository homepage: https://researchrepository.rmit.edu.au

(C) The Authors 2013

Downloaded On 2023/04/26 23:28:55 +1000

Please do not remove this page 
Thank you for downloading this document from the RMIT Research Repository.

The RMIT Research Repository is an open access database showcasing the research outputs of RMIT University researchers.

RMIT Research Repository: http://researchbank.rmit.edu.au/

\section{Citation:}

Wahr, F, Underwood, J, Adams, L and Prideaux, V 2013, 'Three academics' narratives in transforming curriculum for education for sustainable development', Australian Journal of Environmental Education, vol. 29, no. 1, pp. 97-116.

See this record in the RMIT Research Repository at:

https://researchbank.rmit.edu.au/view/rmit:22607

Version: Accepted Manuscript

Copyright Statement: (c) The Authors 2013

Link to Published Version:

http://dx.doi.org/10.1017/aee.2013.21

\section{PLEASE DO NOT REMOVE THIS PAGE}


Fiona Wahr/ Jenny Underwood/ Luise Adams / Verity Prideaux

Three Academics' Narratives in Transforming Curriculum for Education for Sustainable

Development

Published in

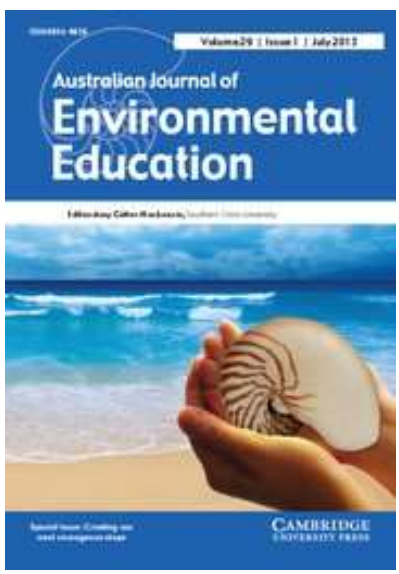

Australian Journal of Environmental Education / Volume 29 / Special Issue 01 / July 2013, pp 97 116

http://journals.cambridge.org/action/displayAbstract?fromPage=online\&aid=8990611\&fulltextTy pe=RA\&fileld $=\$ 0814062613000219$

Published online: 29 August 2013

Copyright (c) The Authors 2013

Citation: Wahr, F., Underwood, J., Adams, L., \& Prideaux, V. (2013). Three academics' narratives in transforming curriculum for education for sustainable development. Australian Journal of Environmental Education, 29(01), 97-116.

Version: Author's pre-print version

Online since July 2015 


\section{Three Academics' Narratives in Transforming Curriculum for Education for Sustainable Development}

\section{Abstract}

The expectation is that higher education curricula which purports to incorporate education for sustainable development (ESD) supports university graduates in becoming more sustainable. It would then follow that if academics are to offer such curricula they need to be adequately equipped with the motivations, knowledge and skills to achieve them. However, the extent to which ESD has resulted in genuine higher education curriculum change, and academic readiness for it, is debateable. As such, this paper presents the academic experiences of three of the authors involved in a curriculum change process to embed ESD within a Bachelor of Arts (Textile Design) degree program. Individual post-project critical self-reflective narratives of our experiences are summarised and thematically analysed. The analysis reveals these experiences as disorienting, yet subsequently transformative. The findings suggest promoting academics' transformative learning should be a focus of ESD curriculum change efforts. The findings support commitment to long term, facilitated professional development to achieve transformative change; an often-espoused, yet under reported phenomenon.

Keywords: education for sustainable development, sustainability, transformative learning, higher education, curriculum change, professional development, narrative

\section{Introduction}

This paper refers to work undertaken within a PhD study by Wahr (co-author of this paper). Wahr's $\mathrm{PhD}$ investigates the role and form of professional development to promote and support sustainability related higher education curriculum change. In early 2009, seven academics (three of whom are coauthors of this paper - Underwood, Adams and Prideaux) teaching into the Bachelor of Arts (Textile Design) joined with Wahr to form 'the group' and commenced the 'Curriculum Change to Embed Sustainability' project.

The project aimed to achieve curriculum change whilst developing academics' (our own) capacity to bring about the change. The project sought to develop a curriculum where textile design graduates would be equipped with the knowledge, skills and attitudes necessary to design and practice more sustainably. Wahr facilitated the project using a collaborative and long-term action research approach. The project was twice awarded in 2011 for embedding sustainability throughout the whole program (Sustainability Victoria, 2012) and for providing an "innovative curriculum change model" (Australian Campuses Towards Sustainability, 2011, p. 10). 

curriculum for education for sustainable development. Australian Journal of Environmental Education, 29(01), 97116.

The paper first considers the role and nature of ESD in universities. The need for transformative professional development to support academics generally to embed sustainability into their curricula is identified and discussed. The paper goes on to present an analysis of our experience of embedding sustainability into the curriculum within the context of the above project. The findings suggest our understandings and practices relating to teaching ESD have been transformed. The characteristics of these transformations are then synthesised and implications of the findings are discussed.

\section{Progressing ESD in higher education}

According to Wals (2009), ESD aims to "develop people's capacities and opportunities to engage with sustainability issues so that they themselves can determine alternative ways of living" (p.27). Proponents of ESD argue for the need to recognise, better understand and address humanity's practices across environmental, economic and social dimensions, which have led to outcomes which put the wellbeing of future generations at risk (Cortese, 1999; Stephens, Hernandez, Román, Graham, \& Scholz, 2008). Yet, "its precise meaning continues to be the subject of worldwide debate" (Wals, 2009, p. 25).

ESD's history, meaning and purpose have been significantly debated (Wals \& Jickling, 2002). ESD has a complex relationship with environmental education. Sterling (2004) sees this relationship as historical, attributing ESD's beginnings to environmental education. Yet ESD is also seen as a contemporary form of environmental education. For Sauvé, ESD is one of the fifteen "currents" or discourses within environmental education, where concern for the environment and "the role [of] education in enhancing human-environment relationships" come together as a core focus for research and practice (2005, p. 15). At the same time Sauvé also sees environmental education as a "tool among others in the cause of sustainable development" (p. 30) where learning is seen as essential to the aims of sustainable development. Indeed, Tilbury (2004a) argues that it is environmental education's "transformative agenda", which "has 'learning for change' at its core aim", which provides the means for higher education to contribute "to building social capacity for change towards sustainability"(p.98) as called for by UNESCO's Agenda 21. Indeed, more recently Tilbury's the call for transformative approaches in higher education continue, albeit with the shifts in terminology which reflect the sectors current engagement with these issues and themes; "the transformation of a university towards sustainable development requires a realignment of all its activities with a critically reflective paradigm which also supports the construction of more sustainable futures" (Tilbury, 2011, p. 19). This paper focuses on this need for transformative learning, which Wals and Blewitt (2012) see as inherent to their understanding of ESD, where 'learning helps people transcend the 'given', the 'ordinary' and the often 'routine ways of doing' to create a new dynamic and alternative ways of seeing and doing" (p. 66). 
pre-print version

Wahr, F., Underwood, J., Adams, L., \& Prideaux, V. (2013). Three academics' narratives in transforming curriculum for education for sustainable development. Australian Journal of Environmental Education, 29(01), 97116.

ESD in higher education is considered a potential and significant driver for improved sustainability as graduates incorporate new understandings and more sustainable practices into their future professional roles (Corcoran \& Wals, 2004; Svanström, Lozano-García, \& Rowe, 2008). ESD, however, has had a limited presence in Australian universities over recent decades with "only a handful of institutions that have embraced it or are working to that point" when surveyed in 2000 (Thomas \& Nicita, 2002, p. 486). Other surveys from the last decade indicate that little had changed in relation to the curriculum, with the focus of ESD efforts in Australian universities being on campus greening activities with primarily niche initiatives in the area of ESD learning and teaching (Lang, Thomas, \& Wilson, 2006; Tilbury, 2004b). This state of affairs is consistent with the view that ESD in higher education in the West, at least, has needed to mature beyond this status-quo, to where it is now in its "third wave", poised to focus "precisely on the teaching and learning implications of sustainability" (Wals \& Blewitt, 2012, p. 57). Invariably, these observations have come with calls for institutional responses to actively strengthen ESD learning and teaching efforts.

A significant challenge for higher education ESD is the capacity of academics to facilitate transformative learning (Sterling, 2010). Professional development for the academics designing and teaching the higher education curriculum is widely seen as a necessary institutional response to promote ESD more extensively across higher education (Wals \& Blewitt, 2012; de la Harpe \& Thomas, 2009). Indeed, lack of ESD related professional development has been seen as a reason for slow progress in establishing ESD progress in Australian universities (Holdsworth, Wyborn, Bekessy, \& Thomas, 2008) when in fact it could be seen as a potentially effective driver of wider institutional change (Barth \& Rieckmann, 2012). Demonstrating the effectiveness of academic professional development to improve student learning is, however, problematic due to the many variables and external factors influencing such validation (McAlpine, Oviedo, \& Emrick, 2008; Southwell \& Morgan, 2009). Assuming, nonetheless, there is value in providing professional development for academics to promote ESD in university curricula, what would it look like?

Consistent with adult learning principles, the prevailing learning context informs the design of a learning experience (Biggs \& Tang, 2007). Understanding academics' perspectives on ESD (including perceived barriers to implementation) and sustainability more broadly, therefore, is a first step to designing appropriate professional development. Academics are likely to have a range of differing perspectives on what sustainability is, ranging from a relatively transactional understanding to one where sustainability is the basis for an individual's worldview (Reid \& Petocz, 2006). Academics may also find aspects of ESD curriculum change as problematic and creating barriers to change. Studies report academics as being uncertain as to how to embed ESD (Jones, Trier, \& Richards, 2008) and being low in confidence to teach ESD (Down, 2006). In addition, academics may see ESD as taking time from other parts of the curriculum (Cowton, 2004; Davis, 2001; Jones, et al., 2008), being too ideological (Cotton et al., 2007); without an agreed definition (Cotton, et al., 2007; Jones, et al., 2008); 
pre-print version

Wahr, F., Underwood, J., Adams, L., \& Prideaux, V. (2013). Three academics' narratives in transforming curriculum for education for sustainable development. Australian Journal of Environmental Education, 29(01), 97116.

highly complex (Down, 2006); without adequate teaching resources (Cowton, 2004); incompatible with the discipline/program (Jones, et al., 2008), and being about "content rather than pedagogy" (Jones, et al., 2008, p. 348). Further, Jones et al. point out that these views could reflect a narrow understanding of sustainability and failure to address these challenges risk pragmatic and onedimensional curriculum changes (Jones, et al., 2008); which would likely be described by Sterling (2004, p. 55) as "accommodation" rather than the higher order "reformation" or even "transformation" necessary to embed ESD. Professional development approaches, then, need to be designed to account for this range of diversity.

Professional development, therefore, would accordingly use "a more holistic approach to [professional] learning" (Jones, et al., 2008, p. 349) where the interconnectedness and multidimensionality of phenomena are recognised and valued within the learning experience (Joseph, 2010). Cranton (2009) sees adult educators as needing to "break free from one-dimensional thought" (p. 100) and to address the approaches which have led to the current profusion of unsustainable practices where adult educators are supported to observe and critique their existing and deeply held social norms, assumptions and paradigms; namely transformative learning as consistent with Wals and Blewitt's (2012) view of ESD itself.

Transformative or fundamental change across higher education is promoted as necessary to reframe and achieve ESD related curricula (Sterling, 2004, 2010). Primary amongst the challenges therefore, is the academic's struggle to interpret and relate the scope of sustainability and ESD pedagogy to their curricula (Jones, et al., 2008).

\section{Transformative learning}

Transformative learning occurs when we "interpret an old experience (or a new one) from a new set of expectations, thus giving a new meaning and perspective to the old experience" (Mezirow, 1991, p. 11). Applied specifically to teaching, it is where "educators are led to examine their practice critically and thereby acquire alternative ways of understanding what they do" (Cranton \& King, 2003, p. 32). Such an approach is underpinned by an "inherent multi-dimensionality" (Wals \& Blewitt, 2012, p. 66) requiring us to look at the world from different perspectives in order to better understand alternatives. ESD is therefore seen as a learning process underpinned by collaborative interaction or social learning (Barth \& Rieckmann, 2012; Wals, 2010; Wals \& Blewitt, 2012).

This examination of perspectives and practices is most often prompted by a "disorienting event" to "stimulate critical reflection" (Cranton, 2009, p. 61); "[a]nomalies and dilemmas of which old ways of knowing cannot make sense become catalysts or 'trigger events' that precipitate critical reflection and transformations" (Mezirow, 1990, p. 5). Change inherently results within the process of transformative 
pre-print version

Wahr, F., Underwood, J., Adams, L., \& Prideaux, V. (2013). Three academics' narratives in transforming curriculum for education for sustainable development. Australian Journal of Environmental Education, 29(01), 97116.

learning as past practices are no longer considered relevant. Such change may result from one event or, more likely, will occur over time (Cranton, 2009).

Cranton and King (2003) use Mezirow's (1990) three forms of self-reflection as a framework for interpreting critical self-reflection in professional development; content reflection (problem recognition, questioning 'what'), process reflection (use of strategies to understand the problem, questioning 'how') and premise reflection (questioning underlying assumptions associated with the problem, questioning 'why'). Consistent with Sterling's view, premise reflection, they advise, provides the greatest likelihood of leading to transformation. Providing professional development which promotes transformative learning can support academics to work towards the holistic approach associated with embedding sustainability in the curriculum.

Academic professional development based upon transformative learning principles recognises that teachers come to the role with existing "habits of mind about teaching" (Cranton \& King, 2003, p. 33) formed over the course of their own personal histories (Cranton \& King, 2003). Decisive self-reflection allows academics to "examine critically what we believe and value in our work as educators" (p. 33).

\section{Supporting transformative learning in adult learning contexts}

Most significantly transformative learning is voluntary; a person cannot be forced to critically reflect (Cranton, 2009). Therefore, transformative learning approaches involve creating the conditions to promote self-critical reflection (Moon, 1999). Moon's conditions include: a learning environment which provides time and space to reflect; facilitation to guide and support reflection; and, a curriculum or program to frame reflection and an emotionally supportive atmosphere. Her recommendation of a clear and goal oriented program frames the purpose of reflection, which is enables further reflection with the use of authentic learning tasks. Learners are challenged to reflect with unstructured tasks needing complex reasoning to address messy problems (Moon, 1999).

Disorienting events, and subsequently transformation, can arise from action and promote action (Taylor, 2008). Action creates a context for reflection where the individual considers what $\mathrm{s} / \mathrm{he}$ has done. According to Taylor, where the action is a disorienting event prompting critical reflection, change in practice will result. Pedagogic strategies suggested to support transformative professional development are participatory and action oriented, including action learning and participatory action research (Bradbury Huang, 2010).

Curriculum development particularly provides an authentic learning environment for academics to collaboratively apply theories to practice and to reflect and critique in-situ (Cranton \& King, 2003) and one where Moon's conditions can be realised. Participatory action research has reportedly been used successfully as the professional development approach in a range of ESD curriculum change 
pre-print version

Wahr, F., Underwood, J., Adams, L., \& Prideaux, V. (2013). Three academics' narratives in transforming curriculum for education for sustainable development. Australian Journal of Environmental Education, 29(01), 97116.

initiatives where academics' ESD practice was reported to increase, see for instance Tilbury, Podger and Reid (2004) where academics embedded ESD into postgraduate courses and Sipos, Battisti and Grimm (2008) involving academics, students and community to develop sustainability related courses. Participatory action research is characterised as "research in action, rather than research about action; a collaborative democratic partnership; research concurrent with action; and, a sequence of events and an approach to problem solving" (Coghlan \& Brannick, 2009, p. 4, italics included in original text). Action learning and action research are similar and often used interchangeably, however, action research is distinguished by a more systematic approach to data collection coupled with an intention to publish aspects of the work (Kember, 2000).

\section{The experience of sustainability transformative change - do we know what it looks like?}

A search of the ESD literature provides examples of the curriculum change process, that is, the tasks undertaken, the broad nature of the change, barriers and drivers and recommendations for academics and collaborators (see for example Hazelton \& Haigh, 2008). Where curriculum changes have been made the literature often presents these as pedagogic and content changes, omitting or only providing a sanitized version of the academics' reflective experience which led to change (see for example Holdsworth, Bekessy, Mnguni, Hayles, \& Thomas, 2006). Specific accounts of transformative learning experiences relating to ESD curriculum change in professional development contexts are not readily available. Such accounts are, however found in academic development literature. Karm (2010) for example, asked academics to write and reflect upon narratives associated with their teaching cases and found these supported improved teaching.

A person's emotional reactions, thinking and decision processes are internal experiences, often hidden from others; a 'black box'. Experience, new understandings and meanings can be inherently assimilated within the individual's worldview and assigned to tacit knowledge (Kohler Riessman, 2008; Mezirow, 1990). Narrative or story reveals the story teller's interpretation of the world (Moon, 2004). Narratives account for and promote recognition of the developmental and continuous nature of transformation (Taylor, 2008) by drawing "[a]ttention to sequences of action" (Kohler Riessman, 2008, p. 11) but can also provide a focus upon the detail or "little things" (Kohler Riessman, 2008, p. 194) of the change experience, offering a closer look into the black box and creating opportunities for deeper insights.

Writing narrative or storied accounts facilitate reflection for the writer (Karm, 2010; Moon, 1999). Narratives promote reflection and transformation by prompting the learner's self-consciousness of their deeper understandings, necessary for transformative learning when academics "step back and observe themselves and to monitor personal change and development" (Karm, 2010, p. 212). From a research perspective, narrative can evidence reflection (Intolubbe-Chmil, Spreen, \& Swap, 2012; Moon, 1999) and provide the data, that when analysed, can identify Cranton and King's levels of 
pre-print version

Wahr, F., Underwood, J., Adams, L., \& Prideaux, V. (2013). Three academics' narratives in transforming curriculum for education for sustainable development. Australian Journal of Environmental Education, 29(01), 97116.

critical self-reflection, which when used in curriculum change settings provide a further source of reflection (see for example Smith, 2009).

Reflective narratives of academics' learning journey which describe the personal experiences of change can therefore offer a means to better understand the responses to complexity and the occurrence and nature of transformative learning needed to promote ESD, particularly in higher education ESD professional development (Sterling, 2010). In seeking to understand how to support academic engagement in ESD related curriculum change, analysis of written personal accounts of such change can provide new insights as to the nature of and impact of ESD professional development. The case of the Bachelor of Arts (Textile Design) ESD curriculum change project provides such an opportunity.

\section{Background to the project}

\section{Curriculum development}

The Bachelor of Arts (Textile Design) at RMIT is a three-year degree program seeking to develop flexible, innovative and creative design practitioners. The program aims for graduates to become leaders in textile design and across the broader global fashion and textile industry and to remain relevant and able to engage in contemporary issues.

Prior to the project, sustainability had been emerging as a potential organising principle for the program (Underwood, 2009). It was however viewed as complex and intractable by most academics in the program. Defining and structuring relevant sustainability knowledge and practice across the program with the appropriate pedagogy was needed.

Sustainability related concepts were present in the program prior to the curriculum change, however, apart from a single first year course these were ad hoc and disparate. Less than a handful of courses included sustainability as a key learning objective and in most instances this was not assessed.

Sustainability was perceived as having an environmental focus amongst academics and students, and included working with recycled materials, using natural fibres and natural/eco colour palettes, and consideration of students' individual design practice, such as the work space at home. Sustainability was taught as a theoretical concept and rarely translated to students' design projects, design practice or their everyday lives. At this time academics reported little exposure to higher education learning and teaching theory, although all were experienced teachers. Amongst the group, one academic had specific textile design related sustainability teaching experience. A sense of disconnect existed between sustainability thinking and the textile design program as a whole. 
pre-print version

Wahr, F., Underwood, J., Adams, L., \& Prideaux, V. (2013). Three academics' narratives in transforming curriculum for education for sustainable development. Australian Journal of Environmental Education, 29(01), 97116.

At the time of writing this paper, the 'Curriculum Change to Embed Sustainability' project had completed two cycles using an action research project approach (Coghlan \& Brannick, 2009). All academics teaching within the program were involved, emphasising the significance of collaboration in action research to promote learning (Bradbury Huang, 2010). The first cycle had been facilitated by Wahr (co-author), using professional development approach where reflective activities were built into a curriculum change project. These were documented in an earlier paper (see Underwood, Wahr, Lynas, \& Beale, 2011). The second cycle was driven by program academics with intermittent involvement by Wahr (see figure 1).

[insert figure 1 here]

Figure 1 - Action research cycles of curriculum change

Consistent with Wals and Blewitt's (2012) view of ESD as a way of learning, rather than conforming to an existing definition, the act of generating a local interpretation of sustainable development informed by multiple perspectives was used as a collaborative learning activity. As a starting point for the project, the group explored and developed themes of our meaning of sustainable development and goals for student learning using a cognitive mapping approach (Lourdel, Gondran, Laforest, Debray, \& Brodhag, 2007). These were not considered definitive as it was envisaged they would change over time, but rather as a reflective activity and a basis for future reflection on change. The following is our interpretation of sustainable development at the time of the first workshop. It is a synthesis of the themes identified by the group arising from the cognitive mapping activity we undertook.

Sustainable development is complex and multidimensional. It seeks long term wellbeing locally and globally by simultaneously considering, balancing and addressing the social, environmental and ethical aspects of humanity's practices. Greater sustainability is achievable. Its achievement relies on learning, problem solving, communication, and preparedness and ability to act and change existing patterns of consumption and use of resources.

The curriculum change process followed a standard approach which initially involved identifying learning context and learner needs, framing learning outcomes, mapping these across the degree and designing appropriate learning activities and assessment tasks (Morrison, Ross, \& Kemp, 2007). A subsequent stage of the project involved curriculum implementation (trialling the new curriculum) and evaluation. During this time the group learning process continued. As we looked closely at our courses and reflected on the impact of the changes, further planning for improvements occurred.

Continuing to critically reflect and a desire to generate new knowledge were an ongoing legacy of the project (Ziegenfuss \& Lawler, 2008). After three years of teaching and continuous improvement 
pre-print version

Wahr, F., Underwood, J., Adams, L., \& Prideaux, V. (2013). Three academics' narratives in transforming curriculum for education for sustainable development. Australian Journal of Environmental Education, 29(01), 97116.

associated with the project, we were aware of significant changes in our understandings and practices. Collaborative conversations continued and opportunities for scholarly work were considered. This paper then draws on the experiences of three of us, Underwood, Adams and Prideaux, which we documented in narrative form.

\section{Using narrative to support and evidence reflection}

We used action learning cycle to frame the self-reflective narratives. We described the planning, actions and review of changes we applied to our ESD teaching over a number of teaching cycles of the same course (Stringer, McFadyen Christensen, \& Baldwin, 2010). We recalled our personal observations, thinking processes and discussions with others. We referred to our own records to prepare the narratives including curriculum documents, journals and notes etc. Being members of a visual discipline and as an additional prompt for reflection, we prepared an annotated visual representation of our experience of the curriculum change process to complement our written accounts (see figures 2, 3, and 4).

\section{The Case Studies: Critical reflection on embedding sustainability within textile design teaching practice}

Each of the three narratives has its own local context, primarily within a single course of the Bachelor of Arts (Textile Design). Whilst the broader context for these narratives is set within the curriculum change project as described above, we all worked in the same program team whilst our personal backgrounds varied considerably. We, excluding Wahr, share textile design backgrounds yet each of us has different sub-discipline expertise, different understandings of and experience with both teaching practice and sustainability. Below is a summary of the narratives. Each narrative refers to a course in a different year level of the program and a different specialism within the program. These short descriptions and visual representations are based on significantly longer narrative texts. The descriptions are provided to give context to the findings and discussion. They include the initial and subsequent changes to courses resulting from the sustainability curriculum change project.

Case Study 1 (CS1) - Prideaux's course is the first year course Textile Studio which includes a student project called 'Craftlife'. Craftlife asked students to consider past and age-old handcrafted textile practices and then to re-conceive and reinvent these in contemporary applications. Arising from the curriculum change, students were also required to incorporate an environmental design approach (cradle-to-cradle) into their practice and to conduct an environmental assessment of their design practice and outcomes. Figure 2 shows a cyclic process of change with elements of reflection, planning, action and review. Large cycles align with the key stages of the group project; curriculum review, design and trialling. Smaller cycles or sub-cycles represent where action learning has been used to work through issues that have arisen within stages of the project. 

curriculum for education for sustainable development. Australian Journal of Environmental Education, 29(01), 97116.

[Insert fig 2 here]

Figure 2 - Visual representation of academic's curriculum change experience in case study 1

Case Study 2 (CS2) - Adams first trialled sustainability teaching amongst third year Computer Aided Textile Design students. Students were asked to conduct a home audit of their workspaces with the view to considering sustainability. A more integrated approach was used for her second year course, Computer Aided Textile Design, within a student project entitled 'What's in a bag?' The 'What's in A Bag" project had a graphic design emphasis and students were required to develop packaging solutions for retail merchandising and point of sale materials. The project's initial sustainability learning task asked students to add a sustainability rationale and approach to the project and they were to critically consider the pros and cons of these alternatives on environmental, business and ethical levels. Figure 3 shows Adams' representation of the experience as a sequence of steps or activities that unfolded during the project and how these relate to each other. The steps show elements of her action learning cycle (i.e. plan, act, review and reflect) but also include highly personalised adaptations by contextualising, extending, and repositioning elements. For example, references to 'meet and discuss' and 'feedback' contextualise the learning within the participatory group process. 'Learn/new insights/attitude' extend the cycle by specifically acknowledging a learning experience. The overlapping and meandering steps suggest a multilayered and undulating experience.

[Insert fig 3 here]

Figure 3 - Visual representation of academic's experience of curriculum change in case study 2

Case Study 3 (CS3) - Underwood embedded sustainability within a project in the final year course Textile Design 3. Textile Design 3 was a practice-led and tutorial based design studio course, where students determined their project direction and outcomes within a set of guidelines. Students were required to apply textile design skills to develop a range of fabrics for a suitable textile outcome to reflect their future career path; be it towards fashion or homewares. Following the sustainability curriculum change, students were asked to propose sustainability concepts that could be incorporated within their design project.

Figure 4 represents the Underwood's experience of change over the duration of the project. Learning and development occurred in primarily two dimensions; the sustainability dimension and the learning and teaching dimension. Underwood develops initially within the sustainability dimension, which is 
pre-print version

Wahr, F., Underwood, J., Adams, L., \& Prideaux, V. (2013). Three academics' narratives in transforming curriculum for education for sustainable development. Australian Journal of Environmental Education, 29(01), 97116.

then complemented with development in the learning and teaching dimension and concludes where the two dimensions are balanced.

[Insert fig 4 here]

Figure 4 - Visual representation of academic's experience of curriculum change in case study 3

We critically questioned each other in regard to our narratives to encourage further reflection similar to Moon's critical incident analysis approach (Moon, 1999). This approach assisted clarification of meaning and interpretation of themes, and provided a form of member checking and inter-coder validity. The full narrative case studies were thematically analysed to identify themes in the academics' experience (Kohler Riessman, 2008). These themes were then further considered in relation to the type of reflection represented in the retelling of these experiences. Examples of the themes are analysed for content, process and/or premise reflection (Cranton \& King, 2003), by considering if there was reflection to identify a problem (content), to understand the nature of the problem (process) and to question the underlying cause or source of the problem (premise). The next section reports the findings of this analysis with sections of the narratives to illustrate the themes and forms of reflection identified.

\section{Findings and Discussion}

The narratives share common attributes which attest to our self-reflective capacity in relation to teaching sustainability. The narratives refer to a range of personal and emotional responses where we question ourselves, including self-doubt "...I also needed to grow in confidence" (CS2), underperformance "I felt the task hadn't really added a lot overall" (CS3) and avoidance "... my way of addressing these concerns was to largely ignore..." (CS3) and uncertainty “... I was uncertain whether the project helps students to narrow the gap between understanding ..." (CS1). We referred to difficulties and challenges we experienced, as well as unexpected outcomes and new insights from teaching the changed courses. Having identified these issues we went on to hypothesise underlying causalities in our own approaches and our subsequent teaching practice, which we critiqued and were open to changing in subsequent course offerings. The following themes emerged. "We" in the following section refers to the narrative authors.

Not starting from scratch - elements of sustainability learning are already there

In the process of identifying the sustainability learning competencies relevant to our discipline, we observed a number of these were already present within the existing curriculum.

Students already had some of this [sustainability] knowledge ... from their $1^{\text {st }}$ year TTI subject (CS2) 
pre-print version

Wahr, F., Underwood, J., Adams, L., \& Prideaux, V. (2013). Three academics' narratives in transforming curriculum for education for sustainable development. Australian Journal of Environmental Education, 29(01), 97116.

I had not expected... [to find]... a number of learning outcomes that were already in place within the course that were important foundations to the programs sustainability objectives. (CS1)

Embedding was then seen more as delineating the existing sustainability learning and building upon and strengthening this, rather than a complete overhaul of the program.

...The challenge, I realised, was to develop a clearer connection, for myself and students, as to how those skills could be used within a brief that focused explicitly on sustainable design outcomes. (CS1)

This suggests sustainability was less foreign and the embedding process less daunting than originally envisaged.

\section{Engage in learning and teaching change}

The narratives reported difficulty teaching the new curriculum with the existing learning and teaching approaches.

I realised clarification within the brief and...linking was required. ...What did I really want students to learn? (CS1)

...so much of this was new and made me think consciously about the how, what and why of learning'. ...I realised I needed to overhaul the...course's overall learning and assessment outcomes. (CS3)

Whilst we saw ourselves as experienced and reflective teachers, the new curriculum required different learning and teaching approaches.

...I was able to identify a number of the sustainability capabilities already being taught, - for example design research skills connects to the University graduate ideal of life-long learners...problem solving. Yet I also saw that these were not explicitly being addressed (for students). My challenge, I realised, was to develop a clearer connection, for myself and students, to how those skills could be used for sustainable design outcomes. (CS1)

We had had little previous exposure to learning and teaching theory and practice. The project included learning and teaching professional development, however, it was not until we tried teaching the new curriculum, that the need for new approaches became evident. 
pre-print version

Wahr, F., Underwood, J., Adams, L., \& Prideaux, V. (2013). Three academics' narratives in transforming curriculum for education for sustainable development. Australian Journal of Environmental Education, 29(01), 97116.

[Learning and teaching theory] was a new language for me. ...The more significant learning process for me has been related to how to teach more effectively, irrespective of the subject matter being delivered. (CS2)

My focus has shifted...to realising I needed to scaffold the student experience and align learning outcomes to assessment. (CS3)

As the project has evolved, I have come to appreciate that there have been two dimensions to the project; learning theory and sustainability. [CS3]

These responses suggest we now saw a greater need for and value in developing teaching approaches informed by learning and teaching theory and practice.

Teach sustainability as a core, holistic concept

Our narratives showed a number of early attempts to teach sustainability resulted in lower than expected student engagement and learning when sustainability was taught as an isolated concept to the rest of the course or with unrelated activities, or when the scope of sustainability was overly narrow compared to the nature of the design task

"I trialled a small sustainability task within the third year textile design course, asking students to write a short statement on how they would incorporate concepts of sustainability within their design project. ... I thought that including a question around sustainability was a way to make sustainability a conscious part of the students design process. ... At the end of the project, I felt the task hadn't really added a lot overall." (CS3)

"We ran a "Session" about sustainability and following this, I asked students to do a home audit of their workspaces with the view to considering sustainability. This exercise bore no relevance to the design tasks that they were undertaking at the time in the subject .... Instead of offering an opportunity for students to engage with notions of sustainability in their design practice, I had in fact been more successful at alienating them from the process!" (CS2)

...I wondered if the project was limiting students by asking them to look at only the one dimension of environmental impact... the stronger projects took a holistic [multidimensional] approach. (CS1)

The narratives suggest we responded to these challenges by changing our courses to integrate sustainability learning more deeply within the course. At the same time, we offered greater learning and teaching support to students to assist them with the greater complexity of the tasks. 

curriculum for education for sustainable development. Australian Journal of Environmental Education, 29(01), 97116.

My [revised] aim was to ensure sustainability was not an add-on and that the assessment was meaningful. ... I didn't want to limit students with a narrow interpretation of sustainability. ... Students begin by focusing on the big picture and then to drill down to the details of their personal experience. ... For me, the embedding of sustainability has led to redefining what sustainability means for textile design practice. (CS3)

I wanted a natural fit so that there wasn't a sense of falseness or 'add-on' allowing the potential for a better connect with the students. ...The project requirements were...a mix of...design challenges. ...so students could immerse themselves in the problem solving that a business might have to engage with. (CS2)

... By giving students the option to look at the social and economic dimensions as well as the environmental, would they get more from the project? ... [D]esign issues associated with the complexity of sustainability could be overwhelming for students... I realised I needed to develop a bridge for students between the delivery of sustainability facts... and the more complex... I have addressed the issues of overwhelming students by reducing the scope of the task and setting a bounded problem. (CS1)

We found making ESD core to the students' learning experience enhanced student learning. Consistent with other research we found teaching sustainability requires addressing the complexity and difficulty of the concept to be a challenge (Mackie \& Kagawa, 2007);a challenge, however, to be addressed and managed rather than avoided.

We and our students are empowered to deal with the challenges that arise In the narratives we reported feeling, to varying degrees, underprepared for teaching sustainability and an associated degree of uncertainty despite variable prior ESD teaching experience.

I also needed to grow in confidence with teaching 'about' sustainability, as I felt underqualified. (CS2)...

For me, teaching sustainability was not new and I consider sustainability core to my teaching practice. Prior to the project commencing, I taught within a first year course, Textile Industry and Technology, concepts relating to sustainability and how to develop design strategies and solutions. I felt I had a solid theoretical knowledge and was confident within this space. In contrast, the third year course did not have a significant sustainability learning component and was not being assessed. I was unsure how to provide a deep engagement with sustainability within this practice-led design context. (CS3) 
We responded to uncertainty by accepting it as part of an open ended learning experience and of the project itself. We worked iteratively to develop our knowledge and skills and to grow deeper insights into the nature of sustainability teaching, as indicated by the diagrams each prepared which depict a dynamic process of change (see figures 2, 3 and 4) and the following narrative extracts.

... at the prototype stage of design...it was almost uniformly difficult to achieve simple sustainability goals. ...despite [students] best efforts there was also a sense of despair at times.

...This leads ultimately to the recognition that sustainability is about a journey and is not in itself an end. ... [it is] interconnectedness and messy, non-linear. (CS2)

Through iterations of the design project my awareness and knowledge around both learning theory and sustainability has increased. (CS3)

As a result of this learning process, we later reported feeling more assured and able to deal with complexity and uncertainty and that we were able to support students to do the same.

As an educator, there is much I have learned. I travelled the same journey as my students, conducted the same research as they did and we have shared information together. (CS2)

Based on the course evaluation surveys, students have responded very positivity to this approach. They liked the opportunity to engage in the big ideas. Students can see that what they are learning and the learning outcomes are relevant. (CS3)

These extracts show we gained confidence in our own capacity to teach ESD within our courses and have developed strategies to assist us to respond to new challenges as they arose during the course of the project.

\section{Reflection and transformation}

The above narrative extracts and diagrams show all three forms of reflection are characteristic of the respective academic's approach to teaching sustainability. Content reflection is evident through the recording of the narratives themselves. The narratives show we were motivated to engage in an open ended and uncertain experience typically found challenging by academics (Wals, 2010). There is a willingness and capacity to consider and examine our sustainability teaching.

Process reflection is evident in the narratives as we have described what we did during the project as well as the action learning process of our sustainability teaching (how we teach ESD) with the diagrams showing dynamic change, steps, stages, and consideration of outcomes. The experience of 
pre-print version

Wahr, F., Underwood, J., Adams, L., \& Prideaux, V. (2013). Three academics' narratives in transforming curriculum for education for sustainable development. Australian Journal of Environmental Education, 29(01), 97116.

operationalizing our ideas, by trying new approaches provided fresh insights and furthered premise reflection (Biggs, 2003; Cranton \& King, 2003).

Premise reflection, where we re-evaluated our underlying understandings is evident from the narrative analyses and related extracts above. Each set of extracts refers to disorienting events, which with critical reflection, rendered pre-existing ideas and approaches no longer applicable. Mapping the curriculum against sustainability learning goals led to the identification of existing but unexpected ESD synergies and the realisation the changes might be less arduous than first thought. Trialling sustainability teaching, whilst provided with learning and teaching support, brought new awareness of and engagement in explicit teaching practices and the value of such approaches. This included the need for sustainability to be a core concept in the textile design curriculum, centrally located in the learning experience and facilitated by appropriate activities enabling students to relate to and grapple with the multifaceted nature of sustainability and its application to design. The realisation of the existence and value of engaging with learning and teaching theory to assist in curriculum change (in addition to sustainability content knowledge enhancement) was an additional shift that we have identified. Overall, we have developed greater resilience to address issues as they arise.

The above analyses highlight the sequential nature of these transformations over the course of the project culminating in the reflective task of writing the narratives. The analyses indicate we have become more empowered in our sustainability teaching through the realisation of greater selfawareness of our understandings and practices, self-enhancement through practice improvement and actual change (Moon, 1999). That is, through our own transformative learning, we can see the need to create transformative learning experiences for our students (Sterling, 2010).

Opening the 'black box' therefore characterises our transformative experience of engaging in sustainability curriculum change as:

- Motivation and preparedness to engage in change;

- Experiencing an individual learning journey of trialling new approaches and challenging preexisting ideas;

- Disorienting experiences and engaging in premise reflection;

- Achieving personal transformations;

- Recognising the personal transformative learning experience; and

- $\quad$ Recognising the significance of creating transformative learning experiences for students.

\section{Reframing barriers to ESD}

This paper highlights the need to reframe how barriers to engaging in ESD curriculum change are understood. Rather than promoting ESD through addressing barriers to curriculum change, efforts to 
pre-print version

Wahr, F., Underwood, J., Adams, L., \& Prideaux, V. (2013). Three academics' narratives in transforming curriculum for education for sustainable development. Australian Journal of Environmental Education, 29(01), 97116.

address barriers to transformation learning might prove more useful. The extent of sustainability knowledge or learning and teaching background has not proven to be a barrier to engaging academics in successful ESD curriculum change, reinforcing the view that there are multiple entry points for academics to engage with sustainability curriculum change (Hegarty, 2008). Further, the inherent complexity of ESD, when addressed appropriately provide rich opportunities for transformative learning (Wals \& Blewitt, 2012). Key to achieving the changes then, is first for those of us seeking to promote professional development for ESD we need "to develop awareness of learner [or in this case academics'] readiness for change" (Taylor, 2008, p. 12). Appropriate responses can then be developed according to context need; holistic approaches should be used where motivation and readiness for change needs to be developed, or where motivation already exists, the approaches to support transformation can be introduced straight way.

The transformative experience of individual academics revealed in this paper must be seen as occurring within a conducive context or a learning environment promoting change consistent with the characteristics identified by Moon (1999). That the change process was facilitated and occurred in a group setting where many of the conditions of transformative learning were met is highly significant, including the consistent motivation to stay engaged, and cannot be underestimated. Of Moon's recommendations the creation of time and space to reflect is particularly important (Wals \& Blewitt, 2012). It is valuable to restate that this project was undertaken over three years and provided many opportunities for us, the academics, involved to plan, trial and evaluate our approaches. The change process was resource intensive and needed time to unfold, but proved successful on many levels and therefore can be considered a worthwhile investment. This then reinforces the argument for ongoing institutional commitment to transformative professional development for academics to support ESD curriculum change.

\section{Conclusion}

The paper has presented analyses of three reflective narratives of our (the co-authors') experience of a facilitated, long term curriculum change project where ESD was embedded in the curriculum. The analysis shows our reflections have led us to re-examine our assumptions and practices and resulted in transformative shifts in thinking and practice over the course of the project to enhance our ESD teaching practice.

The paper reveals the experience of the transformation to be personal in terms of specific outcomes for individual academics based on individual starting points and circumstances. The nature of the transformation, however, was shown to share a common process. Characteristics of this process are a requirement for motivation and preparedness to engage in change amongst academics; experience of an individual learning journey of trialling new approaches and challenging pre-existing ideas; disorienting experiences and engaging in premise reflection; achieving personal transformations; 
pre-print version

Wahr, F., Underwood, J., Adams, L., \& Prideaux, V. (2013). Three academics' narratives in transforming curriculum for education for sustainable development. Australian Journal of Environmental Education, 29(01), 97116.

recognising the personal transformative learning experience; and recognising the significance of creating transformative learning experiences for students.

Sterling (2010) points out that academics need to engage in a their own transformation in order to attain the capacity to teach ESD. It is therefore possible to argue that professional development which is shown to promote transformation for the academics involved is an indicator of efficacy in achieving ESD teaching and subsequent student learning outcomes.

The transformative learning approach to professional development to support ESD used in this study has addressed and resolved issues normally seen as barriers to ESD curriculum change. Addressing barriers to academics' transformation learning therefore should be seen as a first priority in ESD curriculum change efforts. Professional development is needed which creates the necessary transformative learning environment for academics and can be achieved using facilitated, long term and holistic approaches. There remains a challenge to convince university leadership of the need for a commitment to transformative professional development to promote ESD within their institutions and to create the conditions for this to occur.

\section{References}

Australian Campuses Towards Sustainability. (2011). Green gown awards Australasia, 2011 winners.

Retrieved 14/01/2013, from http://www.acts.asn.au/index.php/programs-andinitiatives/green-gown-awards-australasia/green-gown-awards-australasia-2011/2011green-gown-award-australasia-winners/

Barth, M., \& Rieckmann, M. (2012). Academic staff development as a catalyst for curriculum change towards education for sustainable development: an output perspective. Journal of Cleaner Production, 26, 28-36.

Biggs, J. (2003). Teaching for quality learning at university: What the student does (2nd ed.). Berkshire: Open University Press and Two Penn Plaza.

Biggs, J., \& Tang, C. (2007). Teaching for quality learning at university: What the student does (3rd ed.). Berkshire: Open University Press.

Bradbury Huang, H. (2010). What is good action research?: Why the resurgent interest? Action Research, 8(1), 93

Coghlan, D., \& Brannick, T. (2009). Doing action research in your own organization: Sage Publications Ltd. 
pre-print version

Wahr, F., Underwood, J., Adams, L., \& Prideaux, V. (2013). Three academics' narratives in transforming curriculum for education for sustainable development. Australian Journal of Environmental Education, 29(01), 97116.

Corcoran, P. B., \& Wals, A. E. J. (2004). Higher education and the challenge of sustainability : problematics, promise and practice. Dordrecht: Kluwer Academic Publishers.

Cortese, A. (1999). Education for Sustainability: The Need for a New Human Perspective.

Cotton, D. R. E., Warren, M. F., Maiboroda, O., \& Bailey, I. (2007). Sustainable development, higher education and pedagogy: a study of lecturers' beliefs and attitudes. Environmental Education Research, 13(5), 579-597.

Cowton, C. (2004). Accounting education for sustainability. In J. Blewitt \& C. Cullingford (Eds.), The sustainability curriculum: The challenge for higher education (pp. 157-166). London: Earthscan.

Cranton, P. (2009). Transformative learning and AVE for social sustainability. Rethinking Work and Learning, 93-105.

Cranton, P., \& King, K. (2003). Transformative learning as a professional development goal. New Directions for Adult and Continuing Education, 98(Summer), pp 31-37.

Davis, S. A. (2001). Integration of the concepts of sustainability into teaching at post-secondary institutions. Unpublished Doctor of Philosophy, University of Mississippi.

de la Harpe, B., \& Thomas, I. (2009). Curriculum Change in Universities: Conditions that Facilitate Education for Sustainable Development. Journal of Education for Sustainable Development, 3(1), 11.

Down, L. (2006). Addressing the challenges of mainstreaming education for sustainable development in higher education. International Journal of Sustainability in Higher Education, 7(4), 390399.

Hazelton, J., \& Haigh, M. (2008). Incorporating Sustainability into Accounting Curricula: Lessons Learnt From an Action Research Study. Accounting Education, iFirst, 1-20.

Hegarty, K. (2008). Shaping the self to sustain the other: Mapping impacts of academic identity in education for sustainability. Environmental Education Research, 14(6), 681-692.

Holdsworth, S., Bekessy, S., Mnguni, P., Hayles, C., \& Thomas, I. (2006). Beyond leather patches (BELP):Sustainability education at RMIT University. In W. L. Filho \& D. Carpenter (Eds.), Sustainability in the Australasian University Context. Frankfurt am Main: Peter Lang.

Holdsworth, S., Wyborn, C., Bekessy, S., \& Thomas, I. (2008). Professional development for education for sustainability. How advanced are Australian universities? International Journal for Sustainability in Higher Education, 9(2), 131-146. 
pre-print version

Wahr, F., Underwood, J., Adams, L., \& Prideaux, V. (2013). Three academics' narratives in transforming curriculum for education for sustainable development. Australian Journal of Environmental Education, 29(01), 97116.

Intolubbe-Chmil, L., Spreen, C. A., \& Swap, R. J. (2012). Transformative learning: Participant perspectives on international experiential education. Journal of Research in International Education, 11(2), 165-180.

Jones, P., Trier, C. J., \& Richards, J. P. (2008). Embedding Education for Sustainable Development in higher education: A case study examining common challenges and opportunities for undergraduate programmes. International Journal of Educational Research, 47(6), 341-350.

Joseph, P. (2010). Holistic Curriculum. SAGE Publications, Inc. In C. Kridel (Ed.), Encyclopedia of curriculum studies. (pp. 446-448). Thousand Oaks, CA: SAGE Publications, Inc.

Karm, M. (2010). Reflection tasks in pedagogical training courses. International Journal for Academic Development, 15(3), 203-214.

Kember, D. (2000). Action learning and action research. Improving the quality of teaching and learning. London: Kogan Page Ltd.

Kohler Riessman, C. (2008). Narrative methods for the human sciences. Thousand Oaks, California: Sage Publications, Inc.

Lang, J. R., Thomas, I., \& Wilson, A. (2006). Education for sustainability in Australian universities: Where is the action? Australian Journal of Environmental Education, 22(2), 45-58.

Lourdel, N., Gondran, N., Laforest, V., Debray, B., \& Brodhag, C. (2007). Sustainable development cognitive map: a new method of evaluating student understanding. International Journal of Sustainability in Higher Education, 8(2), 170-182.

Mackie, M., \& Kagawa, F. (2007). Opportunities and Challenges for Students and Tutors in Integrating Sustainability into Design Studio Teaching.

McAlpine, L., Oviedo, G. B., \& Emrick, A. (2008). Telling the second half of the story: linking academic development to student experience of learning. Assessment \& Evaluation in Higher Education, 33(6), 661-673.

Mezirow, J. (1990). How critical reflection triggers transformative learning. Fostering critical reflection in adulthood, 1-20.

Moon, J. A. (1999). Reflection in learning and professional development. London: Kogan Page Ltd.

Moon, J. A. (2004). A handbook of reflective and experiential learning. Theory and practice. London: RoutledgeFalmer.

Morrison, G., Ross, S., \& Kemp, J. (2007). Designing effective instruction (5th ed.). Hoboken, NJ Jonh Wiley \& Sons Inc.

Reid, A., \& Petocz, P. (2006). University Lecturers' Understanding of Sustainability. Higher Education: The International Journal of Higher Education and Educational Planning, 51(1), 105-123. 
pre-print version

Wahr, F., Underwood, J., Adams, L., \& Prideaux, V. (2013). Three academics' narratives in transforming curriculum for education for sustainable development. Australian Journal of Environmental Education, 29(01), 97116.

Sauvé, L. (2005). Currents in environmental education: Mapping a complex and evolving. Canadian Journal of Environmental Education (CJEE), 10(1), pp. 11-37.

Sipos, Y., Battisti, B., \& Grimm, K. (2008). Achieving transformative sustainability learning: engaging head, hands and heart. International Journal of Sustainability in Higher Education, 9(1), 6886.

Smith, K. (2009). Transnational teaching experiences: an under-explored territory for transformative professional development. International Journal for Academic Development, 14(2), 111-122. Southwell, D., \& Morgan, W. (2009). Leadership and the Impact of Academic Staff Development and Leadership Development on Student Learning Outcomes in Higher Education: A Review of the Literature: a Report for the Australian Learning and Teaching Council (ALTC): QUT Department of Teaching and Learning Support Services.

Stephens, J., Hernandez, M., Román, M., Graham, A., \& Scholz, R. (2008). Higher education as a change agent for sustainability in different cultures and contexts. International Journal of Sustainability in Higher Education, 9(3), 317-338.

Sterling, S. (2004). An analysis of the development of sustainability education internationally: Evolution, interpretation and transformation. In J. Blewitt \& C. Cullingford (Eds.), The sustainability curriculum: The challenge for higher education (pp. 43-62). London: Earthscan.

Sterling, S. (2010). Transformative learning and sustainability: sketching the conceptual ground. Learning and Teaching in Higher Education(5), 17 - 33.

Stringer, E., McFadyen Christensen, L., \& Baldwin, S. (2010). Integrating teaching, learning and action research: Enhancing instruction in the $K-12$. Thousand Oaks, California: Sage Publications, Inc.

Sustainability Victoria. (2012). Premier's sustainability awards 2012. 2011 Winner: Tertiary education, RMIT University. Retrieved 14/01/2013, from http://sustainabilityawards.vic.gov.au/2011-winner-tertiary-education

Svanström, M., Lozano-García, F. J., \& Rowe, D. (2008). Learning outcomes for sustainable development in higher education. International Journal of Sustainability in Higher Education, 9(3), 339-351.

Taylor, E. W. (2008). Transformative learning theory. New directions for adult and continuing education, 2008(119), 5-15.

Thomas, I., \& Nicita, J. (2002). Sustainability education and Australian universities. Environmental Education Research, 8(4), 475-492. 
pre-print version

Wahr, F., Underwood, J., Adams, L., \& Prideaux, V. (2013). Three academics' narratives in transforming curriculum for education for sustainable development. Australian Journal of Environmental Education, 29(01), 97116.

Tilbury, D. (2004a). Environmental education for sustainability: A force for change. In P. B. Corcoran \& A. E. J. Wals (Eds.), Higher education and the challenge of sustainability. Problematics, Promise and Practice (pp. 97-112). Dordrecht: Kulwer Academic Publishers.

Tilbury, D. (2004b). Rising to the challenge: Education for sustainability in Australia. Australian Journal of Environmental Education, 20(2), 103-114.

Tilbury, D. (2011). Higher Education for Sustainability: A Global Overview of Commitment and Progress. In GUNI (Ed.), Higher Education in the World 4: Higher Education's Commitment to Sustainability from Understanding to Action (pp. 18-28). Barcelona: GUNI Higher Education in the World 4.

Tilbury, D., Podger, D., \& Reid, A. (2004). Action research for change towards sustainability: Change in curricula and graduate skills towards sustainability. Final report.: Australian Government Department of the Environment and Heritage and Macquarie University.

Underwood, J. (2009). 'Re-design: in pursuit of a sustainable future'. In E. Rouse (Ed.), Fashion and Wellbeing? 11th Annual Conference for IFFTI (pp. 482-493). London: International Foundation of Fashion Technology Institutes.

Underwood, J., Wahr, F., Lynas, E., \& Beale, C. (2011). A group approach to embedding sustainability within a degree curriculum: Collaborative, creative, iterative. In K. Hegarty, D. Chambers \& A. Beringer (Eds.), Proceedings of the 10th International Conference of Australasian Campuses Towards Sustainability, 2011 (pp. 63-68). Melbourne, Vic: RMIT, Australasian Campuses Towards Sustainability.

Wals, A. E. J. (2009). Review of context and structures for education for sustainable development 2009. Paris: UNESCO.

Wals, A. E. J. (2010). Mirroring, Gestaltswitching and transformative social learning: stepping stones for developing sustainability competence. International Journal of Sustainability in Higher Education, 11(4), 380-390.

Wals, A. E. J., \& Blewitt, J. (2012). Third wave sustainability in higher education: Some (inter) national trends and developments. In S. Sterling (Ed.), Sustainability education: Perspectives and practice across higher education (pp. 55-74). Hoboken: Earthscan.

Wals, A. E. J., \& Jickling, B. (2002). "Sustainability" in higher education: From doublethink to newspeak to critical thinking and meaningful learning. International Journal of Sustainability in Higher Education, 3(3), 221-232. 


\section{pre-print version}

Wahr, F., Underwood, J., Adams, L., \& Prideaux, V. (2013). Three academics' narratives in transforming curriculum for education for sustainable development. Australian Journal of Environmental Education, 29(01), 97116.

Ziegenfuss, D. H., \& Lawler, P. A. (2008). Collaborative course design: changing the process, acknowledging the context, and implications for academic development. International Journal for Academic Development, 13(3), 151-160.

\section{Author Biographies}

Fiona Wahr is currently completing a PhD at the School of Education, RMIT University which investigates approaches to support academics embedding sustainability in their curricula. She has worked extensively as an academic developer. Her research interests include professional sustainability learning, sustainability related curriculum change and higher education learning and teaching generally.

Dr Jenny Underwood is a lecturer in Textile Design and the Higher Degree by Research Co-ordinator for the School of Fashion and Textile at RMIT University. Her research is trans-disciplinary in approach, exploring sustainability practice for textile design.

Luise Adams is an associate lecturer in Textile Design for the School of Fashion and Textile at RMIT University. She participated in the 'Embedding sustainability into the RMIT University Textile Design curriculum' project. Luise is also a PhD candidate exploring contemporary textile design practice in the context of the emerging craft culture of the 21st century.

Verity Prideaux is a lecturer in Textile Design for the School of Fashion and Textile at RMIT University, where she teaches undergraduate courses in printed textiles and design development. Her main area of interest is traditional surface pattern design for hand printed textiles. 
pre-print version

Wahr, F., Underwood, J., Adams, L., \& Prideaux, V. (2013). Three academics' narratives in transforming curriculum for education for sustainable development. Australian Journal of Environmental Education, 29(01), 97116

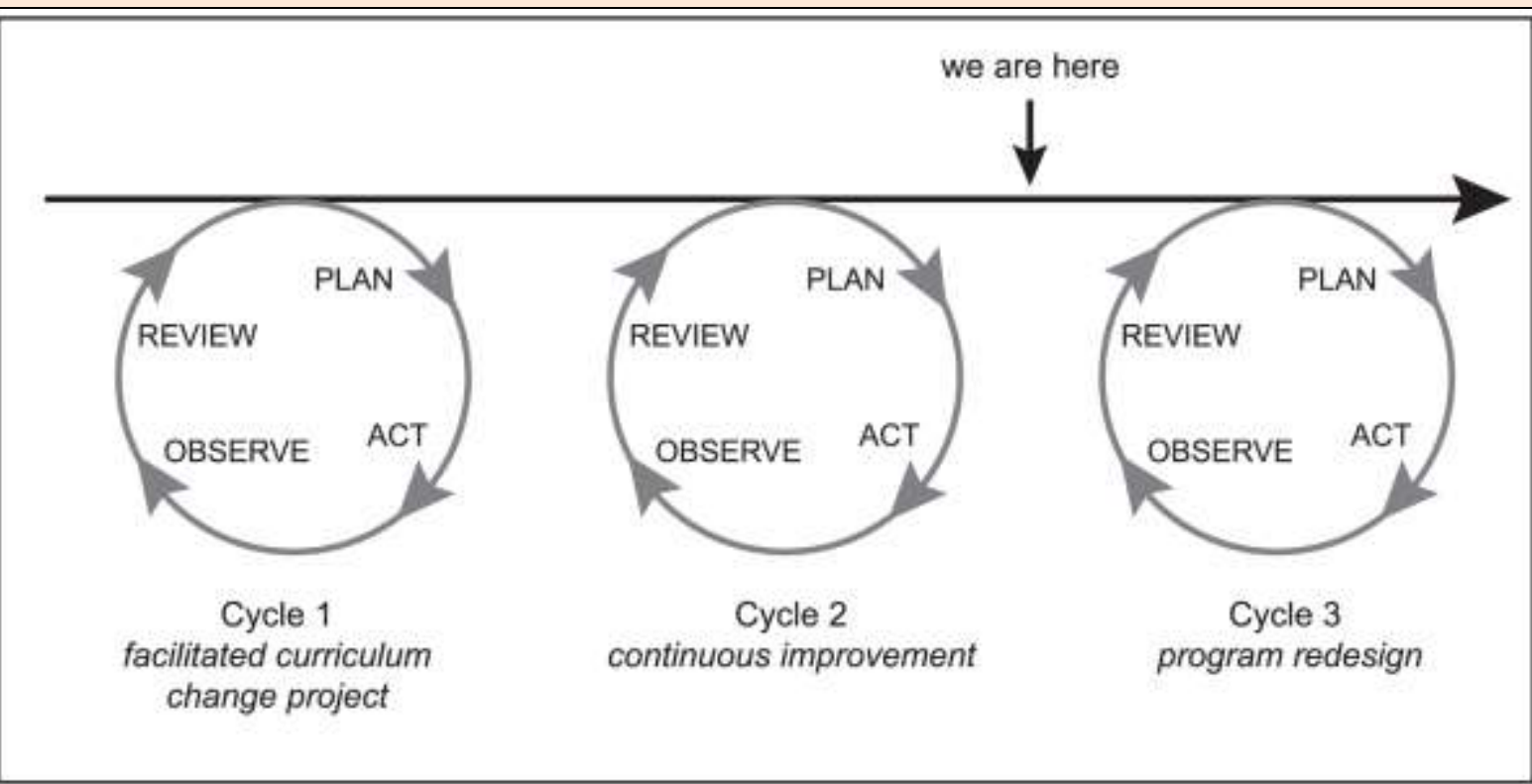

Figure 1: Action Learning Cycles - 'Curriculum Change to Embed Sustainability' project

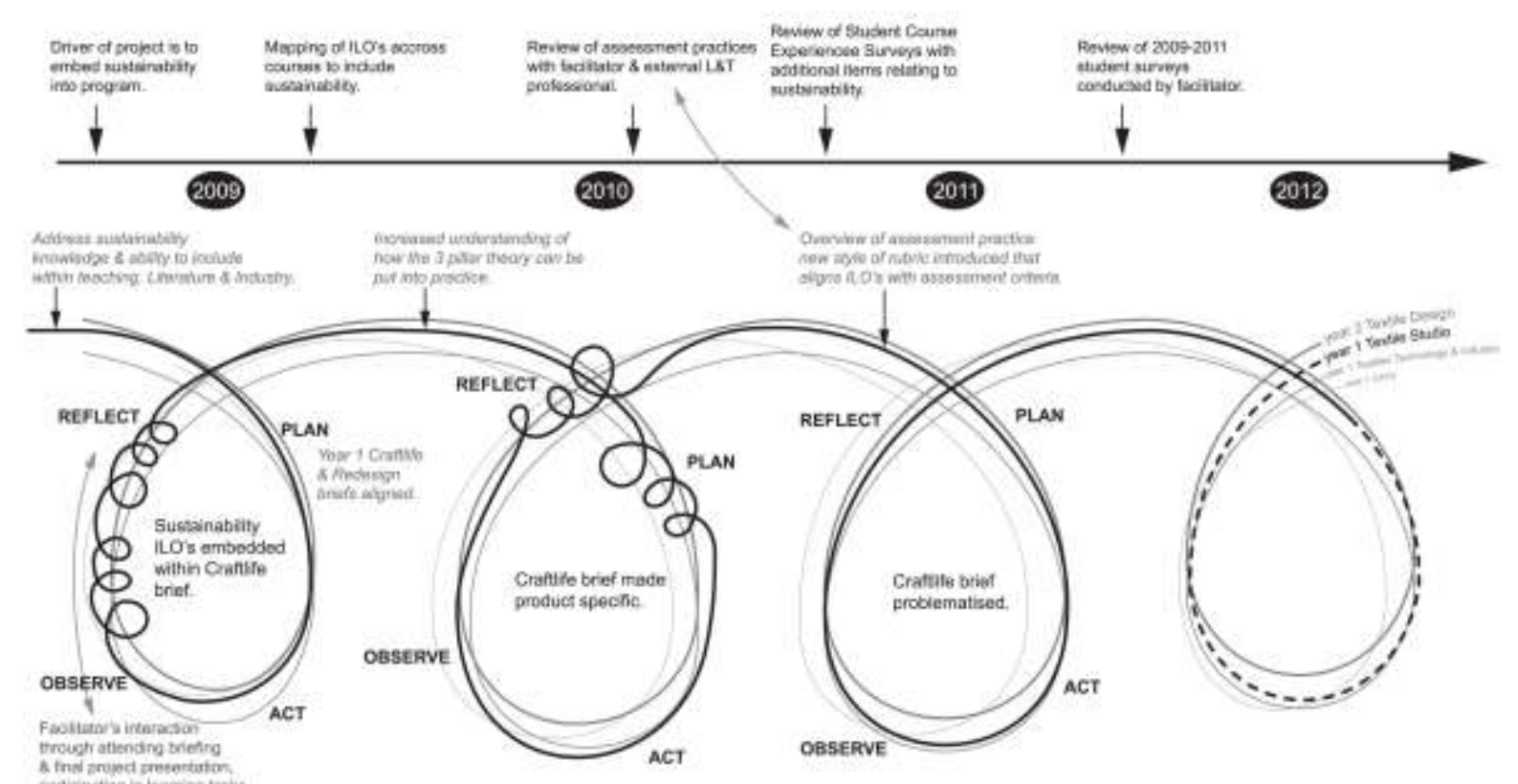

Figure 2 
pre-print version

Wahr, F., Underwood, J., Adams, L., \& Prideaux, V. (2013). Three academics' narratives in transforming curriculum for education for sustainable development. Australian Journal of Environmental Education, 29(01), 97116.
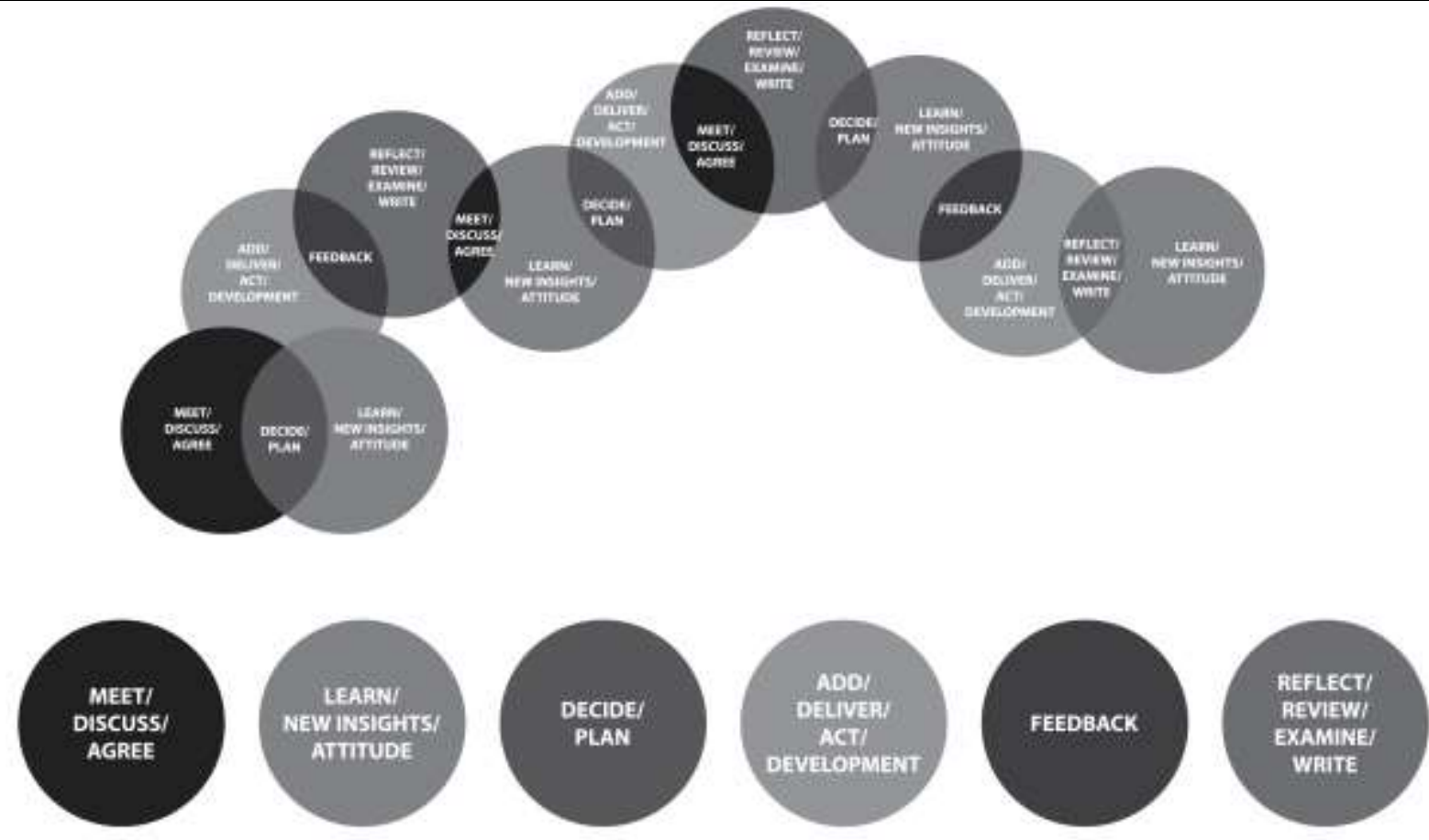

Figure 3

Visual representation of the impact of curriculum change to embed sustainability into the Textile Design 3 A course
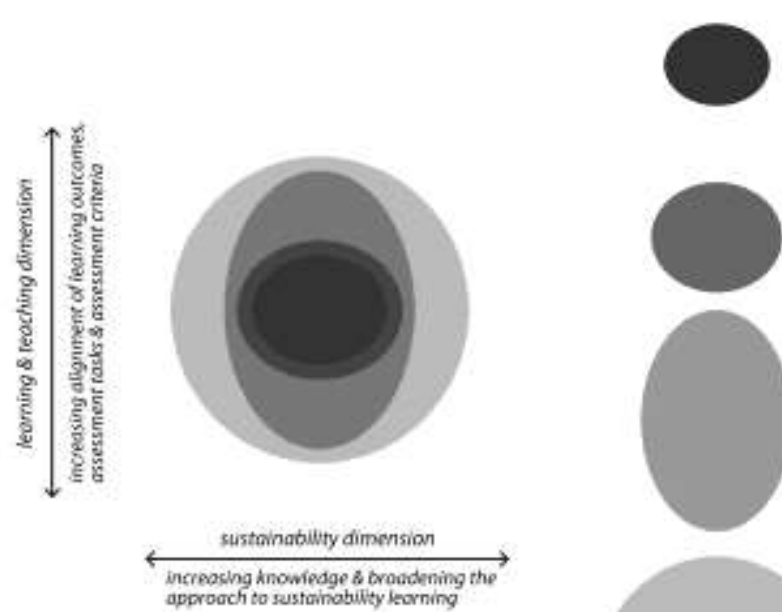

Pniorta 2010 .

present, but nonguly defined.

Students coulf chose to undertake a sustainate design project. - No specifec ieaming ourcame or assessment criteng relating to sustomability. -2009 -Curriculum change project commenced with arogram mopping and planning

2010 (1) sycle of the propect cantinued):

Action - Ploce sustainabiuty ostersment task (wrilten srotement) Within the design project ond assoss the task

fiefiection - Students more aware, but the task is an add-an. Task is Gigned to assessment, but how much om / assessing isustanobility vs writing skills)

2017 (2nd cycle of the praject)

Actian - Ploce surzainuteviny as a ky leaming outcame. Align learning outcams to assessment. Define sustainablity within the

Aeflection - Sustainability is not an add-on, but embedded. However assejsments seems superficial, definition is too simple. Whit exocti

2012 cstort of the 3 ind cycie or the project. Acrian - Dentrie in detoil the dimensians af sustomability within the

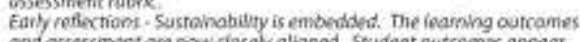
stronger.

Figure 4 